\title{
Endoplasmic Reticulum (ER) Stress Inhibitor or Antioxidant Treatments during Micromanipulation Can Inhibit Both ER and Oxidative Stresses in Porcine SCNT Embryos
}

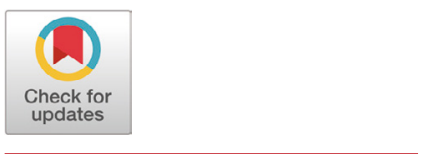

Received: January 9, 2020

Revised: January 17, 2020

Accepted: February 1, 2020

${ }^{\dagger}$ Corresponding author

Hee-Tae Cheong

College of Veterinary Medicine,

Kangwon National University,

Chuncheon 24341, Korea.

Tel: +82-33-250-8659

Fax: +82-33-259-5625

E-mail:htcheong@kangwon.ac.kr

Copyright $\odot 2020$ The Korean Society of Developmental Biology.

This is an Open Access article distributed under the terms of the Creative Commons Attribution Non-Commercial License (http://creativecommons.org/licenses/ by-nc/4.0/) which permits unrestricted non-commercial use, distribution, and reproduction in any medium, provided the original work is properly cited.

ORCID

Hye-Bin Park

https://orcid.org/0000-0001-9972-2190

Yeo-Reum Park

https://orcid.org/0000-0002-6348-9515

Mi-Jeong Kim

https://orcid.org/0000-0002-7244-4781

Bae-Dong Jung

https://orcid.org/0000-0002-6653-9928

Choon-Keun Park

https://orcid.org/0000-0003-2786-8814

Hee-Tae Cheong

https://orcid.org/0000-0001-8225-0262

Conflict of interests

The authors declare no potential conflict of interest.
Hye-Bin Park', Yeo-Reum Park', Mi-Jeong Kim¹, Bae-Dong Jung ', Choon-Keun Park², and 'Hee-Tae Cheong'

'College of Veterinary Medicine and Institute of Veterinary Science, Kangwon National University, Chuncheon 24341, Korea ${ }^{2}$ College of Animal Life Sciences, Kangwon National University, Chuncheon 24341, Korea

\section{Abstract}

We investigated the effects of endoplasmic reticulum (ER) stress inhibitor and antioxidant treatments during the micromanipulation of somatic cell nuclear transfer (SCNT) on in vitro development of SCNT embryos. Tauroursodeoxycholic acid (TUDCA), an ER stress inhibitor and vitamin $\mathrm{C}$ (Vit. C), an antioxidant, were treated by alone or in combination, then, the level of X-box binding protein 1 (Xbp1) splicing and the expressions of ER stress-associated genes, oxidative stress-related genes, and apoptotic genes were confirmed in the 1-cell and blastocyst stages. In the 1-cell stage, the levels of Xbp1 splicing were significantly decreased in TUDCA and Vit. C treatment groups compared to the control $(p<0.05)$. In addition, the expression levels of most ER stress-associated genes and oxidative stress-related genes were significantly lower in all treatment groups than the control $(p<0.05)$, and the transcript levels of apoptotic genes were also significantly lower in all treatment groups than the control $(p<0.05)$. In the blastocyst stage, decreased expression of ER stress-, oxidative stress-, and apoptosis-related genes were observed only in some treatments. However, the blastocyst formation rates in TUDCA and Vit. C treatment groups (24.8\% and $22.0 \%$, respectively) and mean blastocyst cell number in all treatment groups $(59.7 \pm 4.3$ to $63.5 \pm 3.3)$ were significantly higher $(p<0.05)$ than those of control. The results showed that the TUDCA or Vit. $C$ treatment during micromanipulation inhibited both ER and oxidative stresses in the early stage of SCNT embryos, thereby reducing cell damage and promoting in vitro development.

Keywords: Antioxidant, Endoplasmic reticulum stress inhibitor, Micromanipulation, Porcine, Somatic cell nuclear transfer

\section{INTRODUCTION}

In somatic cell nuclear transfer (SCNT) process, physical stresses generated by micromanipulation processes including enucleation, cell injection, fusion, and activation adversely affect the reprogramming 
Acknowledgements

This study was supported by Basic Science

Research Program through the National

Research Foundation of Korea (NRF)

funded by the Ministry of Education

(2016R1D1A1B03930662)

\section{Authors' contributions}

Conceptualization: Cheong HT.

Methodology: Park HB, Park YR, Kim MJ.

Software: Kim MJ.

Validation: Park YR.

Investigation: Park HB.

Writing - original draft: Park HB.

Writing - review \& editing: Jung BD, Park CK, Cheong $\mathrm{HT}$.

Ethics approval

This article does not require IRB/IACUC approval because there are no human and animal participants. of cloned embryos by inducing cellular stresses such as oxidative and endoplasmic reticulum (ER) stresses. (Hwang et al., 2012, 2013; Park et al., 2017; Lee et al., 2018).

Previous studies showed that ER stress and reactive oxygen species (ROS) levels of SCNT embryos were decreased by treatment of ER stress inhibitor and antioxidant during the culture period (Yoon et al., 2014). In general, ER stress inhibitor and antioxidant are treated during the maturation period of oocytes or culture period of embryos (Yoon et al., 2014; Mallol et al., 2015; Lin et al., 2015, 2016). In contrast, previous studies showed that development and quality of SCNT embryos were improved by treating ER stress inhibitors only during microinjection and activation of SCNT, inhibiting ER stress generation during SCNT, and reducing apoptosis (Park et al., 2017; Park et al., 2019). In addition, the ROS and apoptosis were reduced when antioxidant was treated during micromanipulation, fusion and activation of SCNT process (Bae et al., 2012,2015).

An intimate correlation between ER stress and oxidative stress has been demonstrated by many physiological and pathological studies (Cullinan \& Diehl, 2006; Malhotra \& Kaufman, 2007; Malhotra et al., 2008; Bhandary et al., 2012; Zeeshan et al., 2016). Previous researches have demonstrated that ER stress and ROS are not only occurring simultaneously, but also inducing one another (Cullinan \& Diehl, 2006; Eletto et al., 2014; Zhang et al., 2015; Zeeshan et al., 2016). In addition, PKR-like ER kinase (PERK), one of the unfolded protein response (UPR) sensors, regulates the expression of detoxifying enzymes and genes involved in protein folding by inducing the phosphorylation of the nuclear factor (erythroid-derived 2) 2 ( Nrf2), the master key of the antioxidative response (Cullinan \& Diehl, 2006; Bhandary et al., 2012; Zeeshan et al., 2016). Conversely, high levels of ROS have been reported to promote ER stress by damaging cellular proteins such as abnormal folding, aggregation and fragmentation, inhibiting protein production and transport, and destroying calcium homeostasis (Malhotra \& Kaufman, 2007; Vannuvel et al., 2010; Sano \& Reed, 2013). However, it is unclear how the correlation between ER stress and ROS affects the reprogramming and development of early embryos.

Taken together, the intimate interaction between ER stress and oxidative stress, which are generated during micromanipulation, may interactively affect the development and reprogramming of SCNT embryos. Thus, it is surmised that ER stress inhibitor and antioxidant treatments during SCNT may effectively inhibit cell damage and promote the reprogramming of SCNT embryos. In this study, we focused on the close interaction between ER stress and ROS during SCNT process. Thus, we investigated the effects of the treatment of tauroursodeoxycholic acid (TUDCA), an ER inhibitor, and vitamin $\mathrm{C}$ (Vit. C), an antioxidant during micromanipulation, on the ER stress and oxidative stress of SCNT embryos, and on the cell damage and development of SCNT embryos.

\section{MATERIALS AND METHODS}

\section{Chemical reagents}

All chemicals and reagents were supplied by Sigma-Aldrich Chemical Co. (St. Louis, MO, USA) unless otherwise specified. Vit. C and TUDCA (Merck, Darmstadt, Germany) stocks dissolved in phosphate buffered saline (PBS, Gibco, Grand Island, NY, USA) were stored at $-20^{\circ} \mathrm{C}$ until use.

\section{In vitro maturation of oocytes}

Porcine cumulus-oocyte complexes (COCs) were aspirated from follicles ( 3 to $6 \mathrm{~mm}$ in diameter) using 18-gauge needle $10 \mathrm{~mL}$ syringe. COCs were washed with Tyrode's lactate (TL)HEPES buffer containing $0.1 \%(\mathrm{w} / \mathrm{v})$ polyvinyl alcohol (PVA), then cultured in in vitro maturation 
(IVM) medium for $42-44 \mathrm{~h}$ at $39^{\circ} \mathrm{C}, 5 \% \mathrm{CO}_{2}$ in air. IVM medium was Tissue Culture Medium 199 (TCM199; Gibco) supplemented with 0.1\% (w/v) PVA, $3.05 \mathrm{mM}$ D-glucose, $0.91 \mathrm{mM} \mathrm{Na}$ pyruvate, $0.57 \mathrm{mM}$ cysteine, $75 \mu \mathrm{g} / \mathrm{mL}$ penicillin $\mathrm{G}, 50 \mu \mathrm{g} / \mathrm{mL}$ streptomycin, $0.01 \mathrm{IU} / \mathrm{mL}$ follicle stimulating hormone (FSH), $0.01 \mathrm{IU} / \mathrm{mL}$ luteinizing hormone (LH), and $10 \mathrm{ng} / \mathrm{mL}$ epidermal growth factor (EGF).

\section{Preparation of donor cells}

Porcine ear skin cells were cultured in Dulbecco's modified Eagle's medium (DMEM; Gibco) supplemented with 10\% fetal bovine serum (FBS; GenDEPOT, Katy, TX, USA) and 1\% (w/v) penicillin and streptomycin $\left(\mathrm{P} / \mathrm{S}\right.$; Mediatech, Manassas, VA, USA) at $39^{\circ} \mathrm{C}, 5 \% \mathrm{CO}_{2}$ in air. The cells were passaged 2-3 times and frozen using DMEM containing 10\% dimethyl sulfoxide (DMSO; Junsei Chemical, Tokyo, Japan) and stored in liquid nitrogen. Prior to SCNT, cells were thawed and cultured in DMEM containing $15 \% \mathrm{FBS}$ and $1 \%(\mathrm{w} / \mathrm{v}) \mathrm{P} / \mathrm{S}$ at $39^{\circ} \mathrm{C}, 5 \% \mathrm{CO}_{2}$ in air until they reached confluence to synchronize the cell cycle stage at the G0/G1 phase. Cells were trypsinized with $0.05 \%$ (w/v) trypsin-EDTA (Gibco) and washed by centrifugation (500×g, $4 \mathrm{~min}$, room temperature) in Hepes-buffered TCM199 supplemented with $0.78 \mathrm{mM}$ sodium bicarbonate, 0.08 $\mathrm{mM}$ streptomycin, $0.14 \mathrm{mM}$ penicillin $\mathrm{G}$, and $3 \mathrm{mg} / \mathrm{mL}$ bovine serum albumin (BSA). Donor cells were placed in a $500 \mu \mathrm{L}$ well of the same medium for use.

\section{Nuclear transfer}

The cumulus cells of maturated oocytes were eliminated by vortexing in PBS containing $0.1 \%$ $(\mathrm{w} / \mathrm{v})$ hyaluronidase and $0.1 \%(\mathrm{w} / \mathrm{v})$ polyvinyl pyrrolidone (PVP) for $3 \mathrm{~min}$. Enucleation of oocytes was conducted by removing the metaphase II (MII) first polar body and chromosome mass using injection pipette in the micromanipulation medium of Hepes-buffered TCM-BSA containing 5 $\mu \mathrm{g} / \mathrm{mL}$ cytochalasin B. More than $90 \%$ of the oocytes were enucleated with this method (data not shown). A single donor cell was then injected into the perivitelline space of an enucleated oocyte.

\section{Electrofusion/activation}

Reconstructed oocytes were placed in Porcine zygote medium-3 (PZM-3, holding medium) for 10-30 min prior to electrofusion. Then, they were placed and aligned between two wire electrodes (1 mm apart) of an electrofusion chamber, overlaid with $0.3 \mathrm{M}$ mannitol solution containing 0.1 $\mathrm{mM} \mathrm{MgCl} 2,0.1 \mathrm{mM} \mathrm{CaCl}$ and $0.5 \mathrm{mM}$ Hepes (Duchefa Biochemie, Haarlem, Netherlands). For electrofusion/activation, a single direct current pulse of $1.25 \mathrm{kV} / \mathrm{cm}$ was applied for $30 \mu \mathrm{sec}$ using a BTX Electro Cell Manipulator 200 (BTX, San Diago, CA, USA). After fusion/activation, the reconstituted oocytes were placed in holding medium at $39^{\circ} \mathrm{C}, 5 \% \mathrm{CO}_{2}$ in air and checked for fusion.

\section{ER stress inhibitor and antioxidant treatments}

For the treatment groups, $100 \mu \mathrm{M}$ TUDCA (Park et al., 2019), $100 \mu \mathrm{M}$ Vit. C (Bae et al., 2012), or both TUDCA and Vit. C (TUD+Vit. C) were added to micromanipulation medium and holding medium prior to fusion of reconstituted oocytes. After fusion/activation, the reconstituted oocytes for the treatment group were further incubated in the PZM-3 medium containing ER stress inhibitors and/or antioxidant (TUDCA, Vit. C or TUD+Vit. C, respectively) of each concentration at $39^{\circ} \mathrm{C}, 5 \% \mathrm{CO}_{2}$ in air for $3 \mathrm{~h}$.

\section{In vitro culture and sampling}

After fusion/activation (control) or treatment of ER stress and oxidative stress inhibitors, SCNT 
embryos were cultured in a $40 \mu \mathrm{L}$ droplet of fresh PZM-3 medium at $39^{\circ} \mathrm{C}, 5 \% \mathrm{CO}_{2}$ in air for up to 6 days. At the 1-cell stage $(20 \mathrm{~h})$ or blastocyst stage ( 6 days), the embryos were washed in PBS supplemented with $0.3 \%$ (w/v) PVP (PBS-PVP) and lysed by using $30 \mu \mathrm{L}$ of Lysis/Binding (L/B) buffer of Dynabeads ${ }^{\circledR}$ mRNA Direct kit ${ }^{\mathrm{TM}}$ (Life Technologies, Oslo, Norway). The lysed embryo samples were stored at $-70^{\circ} \mathrm{C}$ until use.

\section{Counting of cell number}

The blastocysts were washed with PVP-PBS, then stained with $20 \mu \mathrm{g} / \mathrm{mL}$ of Hoechst 33342 for $30 \mathrm{~min}$. After staining, the embryos were mounted on a slide glass with Vecta-Shield (Vector Laboratories, Burlingame, CA, USA) and covered with a coverslip. The number of cells in blastocysts were counted by using a fluorescence microscopy (BX50, Olympus, Tokyo, Japan).

\section{9. mRNA extraction and CDNA synthesis}

Poly(A) mRNA of the SCNT embryos was isolated by using Dynabeads ${ }^{\circledR}$ mRNA Direct $\mathrm{kit}^{\mathrm{TM}}$ (Life Technologies) according to the manufacturer's protocols. The cryopreserved embryo samples were thawed and mixed with $30 \mu \mathrm{L}$ of Dynabeads oligo $(\mathrm{dT})_{25}$ by shaking for $8 \mathrm{~min}$ at room temperature to allow the hybridization of poly (A) tail of mRNA with the oligo $(\mathrm{dT})_{25}$ on the beads. The Beads-mRNA complexes were washed twice with $100 \mu \mathrm{L}$ of wash buffer A and $\mathrm{B}$, respectively. Beads were separated from supernatant by using a DynaMag ${ }^{\mathrm{TM}}-$ Spin Magnet (Invitrogen, Carlsbad, CA, USA). The poly (A) mRNA was eluted from beads by incubation with elution buffer $(12.5 \mu \mathrm{L}$ of $10 \mathrm{mM}$ Tris- $\mathrm{HCl})$ for $5 \mathrm{~min}$ at $70^{\circ} \mathrm{C}$. The cDNA synthesis was performed using AccuPower ${ }^{\circledR}$ RocketScript ${ }^{\mathrm{TM}}$ Cycle RT Premix (Bioneer, Daejeon, Korea) according to the manufacturer's protocol. Each $10 \mu \mathrm{L}$ mRNA was used as a template. The reaction was carried out in Veriti ${ }^{\circledR}$ 96-well Thermo cycler (Applied Biosystems, Foster City, CA, USA) by 5 cycles of $4^{\circ} \mathrm{C}$ for $5 \mathrm{~min}, 37^{\circ} \mathrm{C} 15 \mathrm{sec}, 50^{\circ} \mathrm{C}$ for $5 \mathrm{~min}$, and $98^{\circ} \mathrm{C}$ for $5 \mathrm{~min}$. The cDNA products were stored at $4{ }^{\circ} \mathrm{C}$ until use.

\section{Semiquantitative polymerase chain reaction (semi-qPCR) and real-time quantitative RT-PCR (RT-qPCR)}

Semi-qPCR analysis was used to detect the Xbp1 mRNA expression. The expressions of ER stress-associated genes such as binding protein (BiP), glucose-regulated protein 94 (GRP94), C/ EBP homologous protein $(C H O P)$, and activating transcription factor 4 (ATF4), and apoptotic genes such as $\mathrm{Bcl} 2$-associated $\mathrm{X}$ protein $(B a x)$ and caspase-3, and oxidative stress-associated genes, such as $N r f 2$ and hemeoxygenase 1 (HO-1) were analyzed by RT-qPCR. For Semi-qPCR, the cDNA sample was reverse-transcribed using AccuPower ${ }^{\circledR}$ Taq PCR PreMix (Bioneer) according to the manufacturer's protocol. PCR conditions were consisted of a denaturation at $95^{\circ} \mathrm{C}$ for $30 \mathrm{sec}$, an annealing at $58^{\circ} \mathrm{C}$ for $30 \mathrm{sec}$, and an extension at $72^{\circ} \mathrm{C}$ for $5 \mathrm{~min}$. The PCR products were analyzed by UV irradiation with a Gel Doc ${ }^{\mathrm{TM} X R}+$ (Bio-rad, Berkeley, CA, USA) on 4\% agarose gel (Amresco, Cleveland, OH, USA) supplemented with 0.05\% ethidium bromide (Bioneer). RT-qPCR was performed using $1 \mu \mathrm{L}$ cDNA with SYBR Green PCR Master Mix (TOPreal ${ }^{\mathrm{TM}}$ qPCR 2X PreMIX; SYBR Green with high ROX, Enzynomics, Daejeon, Korea). The amplification reaction was performed in a StepOne Plus instrument (Applied Biosystems) by 40 cycles of a denaturation at $95^{\circ} \mathrm{C}$ for $30 \mathrm{sec}$, an annealing at $60^{\circ} \mathrm{C}$ for $30 \mathrm{sec}$, and an extraction at $72^{\circ} \mathrm{C}$ for $30 \mathrm{sec}$. The comparative CT method ( $\triangle \Delta \mathrm{CT}$ method) was used for the relative mRNA quantification of each target gene. Glyceraldehyde 3-phosphate dehydrogenase (GAPDH) was used as a housekeeping gene. Primer pairs synthesized for the primer sequences of each gene are shown in Table 1. 
Table 1. All primer sequences used for RT-PCR and RT-qPCR

\begin{tabular}{|c|c|c|c|c|}
\hline Genes & Primer sequences $\left(5^{\prime}-3^{\prime}\right)$ & $\begin{array}{l}\text { Length } \\
\text { (bp) }\end{array}$ & $\begin{array}{c}\text { GenBank } \\
\text { Acc No. }\end{array}$ & $\begin{array}{l}\text { Annealing } \\
\text { temp }\left({ }^{\circ} \mathrm{C}\right)\end{array}$ \\
\hline \multirow{2}{*}{ Xbp1 } & F-GGCAGAGACCAAGGGGAATG & \multirow{2}{*}{263} & \multirow{2}{*}{ FJ213449.1 } & \multirow{2}{*}{60} \\
\hline & R-GGGTCGACTTCTGGGAGCTG & & & \\
\hline \multirow{2}{*}{$\mathrm{BiP}$} & F-ACCAATGACCAAAATCGCCT & \multirow{2}{*}{246} & \multirow{2}{*}{ J03214.1 } & \multirow{2}{*}{60} \\
\hline & R-GTGACTTTCCAGCCACTCAA & & & \\
\hline \multirow{2}{*}{ GRP94 } & F-CTGCTGAAGGGGAA TTACC & \multirow{2}{*}{197} & \multirow{2}{*}{ Y09136.1 } & \multirow{2}{*}{60} \\
\hline & R-ATCATCTGAGTCCACAACGC & & & \\
\hline \multirow{2}{*}{ ATF4 } & F-TGAGCCCTGACTCCTATCTG & \multirow{2}{*}{277} & \multirow{2}{*}{ NM_001123078.1 } & \multirow{2}{*}{60} \\
\hline & R-TCCAGCTCTTTACATTCGCC & & & \\
\hline \multirow{2}{*}{$\begin{array}{l}\text { CHOP } \\
\text { (DDIT3) }\end{array}$} & F-AAGACCCAGGAAACGGAAAC & \multirow{2}{*}{261} & \multirow{2}{*}{ NM_001144845.1 } & \multirow{2}{*}{60} \\
\hline & R-TCCAGGAAAGGTCAGCAGTA & & & \\
\hline \multirow{2}{*}{$\begin{array}{c}\text { Nrf2 } \\
\text { (NFE2L2) }\end{array}$} & F-CCСАTTCACAAAAGACAAАСАTTC & \multirow{2}{*}{72} & \multirow{2}{*}{ GU991000.1 } & \multirow{2}{*}{60} \\
\hline & R-GCTTTTGCCCTTAGCTCATCTC & & & \\
\hline \multirow{2}{*}{$\begin{array}{c}\mathrm{HO}-1 \\
\text { (HMOX1) }\end{array}$} & F-CACTCACAGCCCAACAGCA & \multirow{2}{*}{162} & \multirow{2}{*}{ NM_001004027.1 } & \multirow{2}{*}{55} \\
\hline & R-GTGGTACAAGGACGCCATCA & & & \\
\hline \multirow{2}{*}{ Bax } & F-ACTGGACAGTAACATGGAGC & \multirow{2}{*}{294} & \multirow{2}{*}{ XM003127290.3 } & \multirow{2}{*}{55} \\
\hline & R-GTCCCAAAGTAGGAGAGGAG & & & \\
\hline \multirow{2}{*}{ Caspase-3 } & F-GAGGCAGACTTCTTGTATGC & \multirow{2}{*}{237} & \multirow{2}{*}{ NM_214131 } & \multirow{2}{*}{60} \\
\hline & R-CATGGACACAATACATGGAA & & & \\
\hline GAPDH & F-GGGCATGAACCATGAGAAGT & 230 & AF017079 & 58 \\
\hline 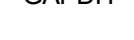 & R-AAGCAGGGATGATGTTCTGG & 200 & 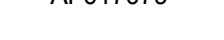 & ( \\
\hline
\end{tabular}

Xbp1, X-box binding protein 1; BiP, binding protein; GRP94, glucose-regulated protein 94; ATF4, activating transcription factor 4; CHOP, C/EBP homologous protein; Nrf2, nuclear factor 2; HO-1, hemeoxygenase $1 \mathrm{GAPDH}$, glyceraldehyde 3-phosphate dehydrogenase.

\section{Statistical analysis}

At least 5 replicates were conducted for each statistical analysis. Data of semi-qPCR and RTqPCR were analyzed by the general linear model (GLM) and the Duncan's multiple range test. The developmental rate was analyzed by Chi-square test, and the blastocyst cell number was analyzed by Student $t$-test. All analyses were performed using the Statistical Analysis System software package (v.9.4, SAS Institute, Cary, NC, USA).

\section{RESULTS}

\section{Effects of ER stress inhibitor and antioxidant on the ER stress, oxidative stress, and apoptosis of SCNT 1-cell embryos}

TUDCA and Vit. C treatment groups showed the significant reduction of $X b p 1$ splicing compared to the control group at the 1-cell stage $(p<0.05)$. However, $X b p 1$ splicing in the combined group (TUD+Vit. C) was not different from that of the control group (Fig. 1A).

The expressions of ER stress-associated genes BiP, GRP94,ATF4, and $C H O P$ were significantly decreased in all treatment groups compared to the control group $(p<0.05)$, except $B i P$ in Vit. $\mathrm{C}$ and TUD+Vit. C treatment groups, and GRP94 in Vit. C treatment group (Fig. 1B).

The expressions of oxidative stress-associated genes $\mathrm{Nrf} 2$ and $\mathrm{HO}-1$ tend to decrease in all treatment groups (Fig. 1C). Nrf2 expression was significantly decreased by TUDCA and TUD+Vit. $\mathrm{C}$ treatments, and $H O-1$ expression was significantly decreased by all treatments compared to control $(p<0.05)$. 
A
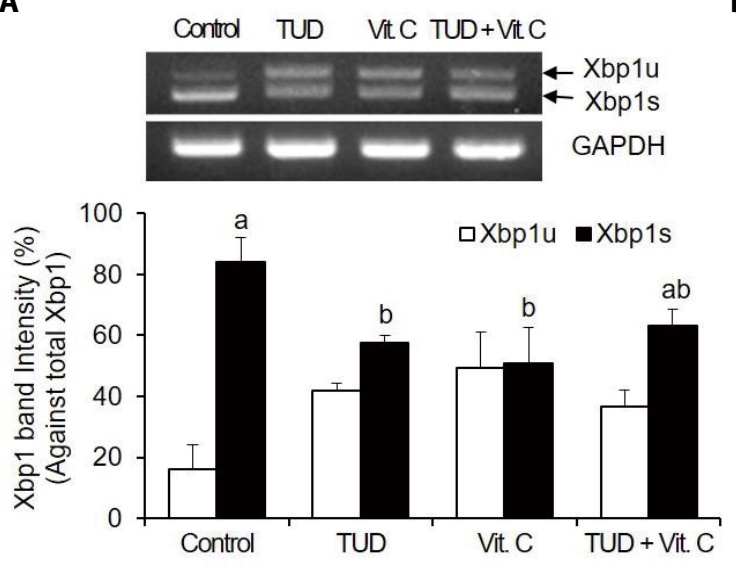

$c$

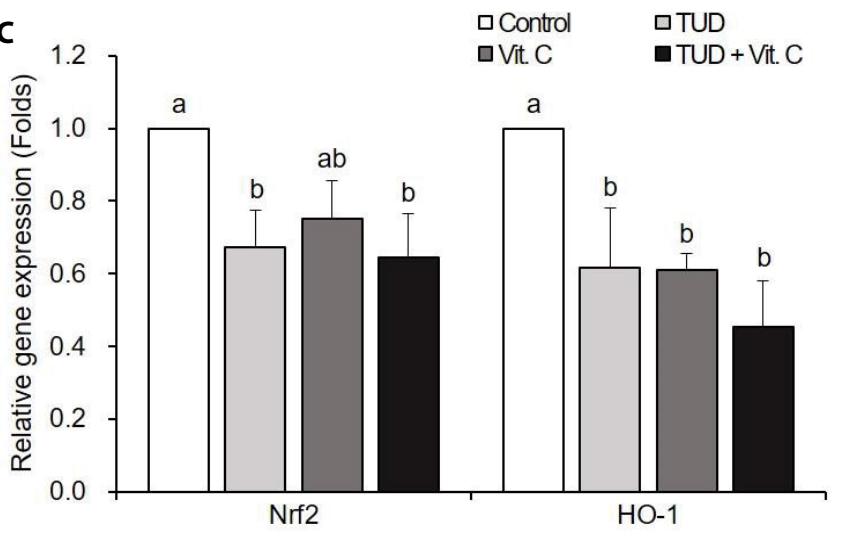

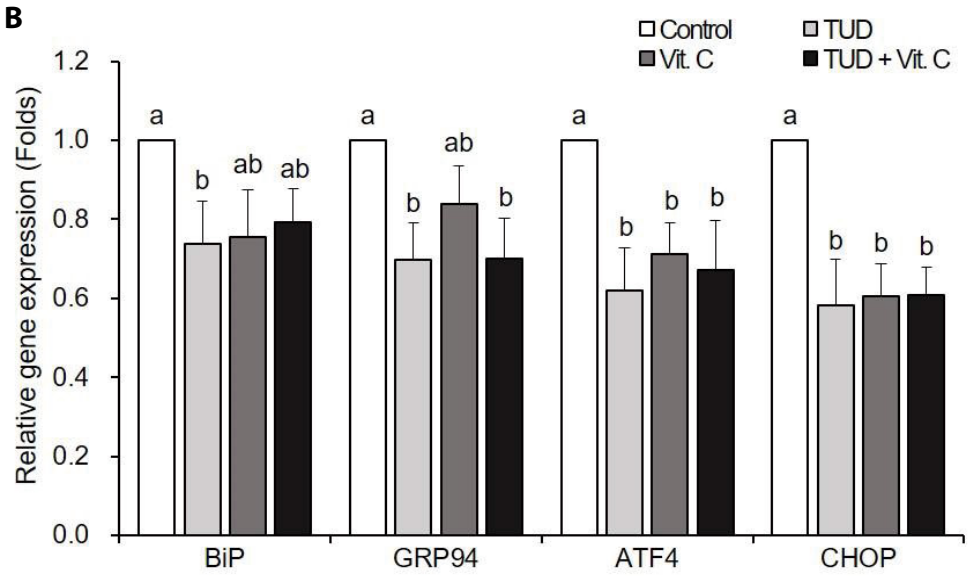
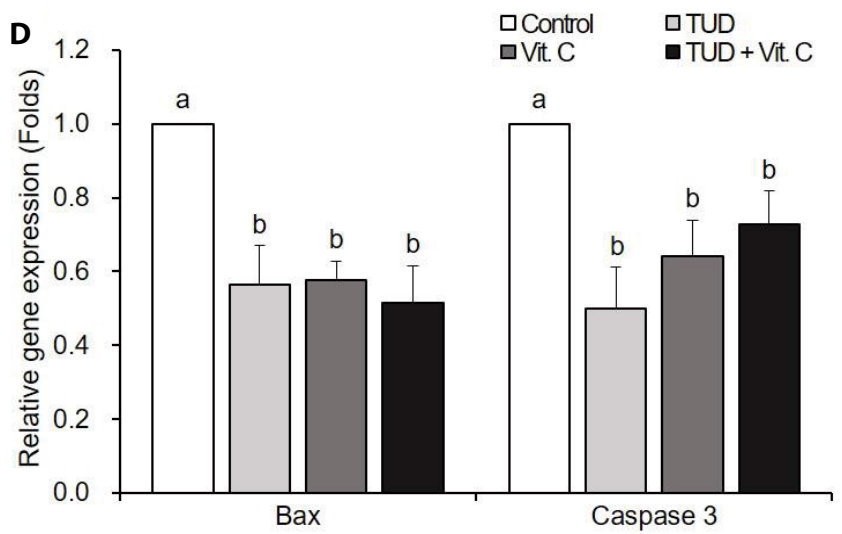

Fig. 1. Expression of Xbp1 mRNA (A), endoplasmic reticulum (ER) stress-associated genes (B), oxidative stress-associated genes (C), and apoptotic genes (D) in somatic cell nuclear transfer (SCNT) embryos at the one-cell stage. Data are presented as means \pm SEM. TUD, 100 $\mu \mathrm{M}$ TUDCA (tauroursodeoxycholic acid); Vit. C, $100 \mu \mathrm{M}$ vitamin C; Xbp1s, spliced Xbp1; Xbp1u, unspliced Xbp1. ${ }^{\text {a,b }}$ Values with different letters are significantly different $(p<0.05)$.

The transcription levels of pro-apoptotic genes Bax and caspase-3 mRNAs were significantly decreased $(p<0.05)$ in all treatment groups compared to the control group (Fig. 1D).

\section{Effects of ER stress inhibitor and antioxidant on the ER stress, oxidative stress, and apoptosis of SCNT blastocysts}

There were no significant differences in $X b p 1$ splicing among all groups (Fig. 2A).

The Vit. C treatment did not reduce the expression levels of ER stress-associated genes of porcine SCNT embryos at the blastocyst stage (Fig. 2B). However, TUDCA treatment significantly reduced the expression levels of $B i P, G R P 94$, and $A T F 4$, and the TUD+Vit. $\mathrm{C}$ treatment reduced only ATF4 transcription level $(p<0.05)$.

At the blastocyst stage, ER stress inhibitor and antioxidant treatments significantly decreased $(p<0.05)$ the expressions of oxidative stress-associated gene HO-1, but not $N r f 2$ (Fig. $2 \mathrm{C}$ ).

There were no significant differences in Bax mRNA expression compared to control (Fig. 2D). However, the transcription levels of caspase-3 mRNA significantly reduced in all treatment groups compared to the control group $(p<0.05)$. 
A
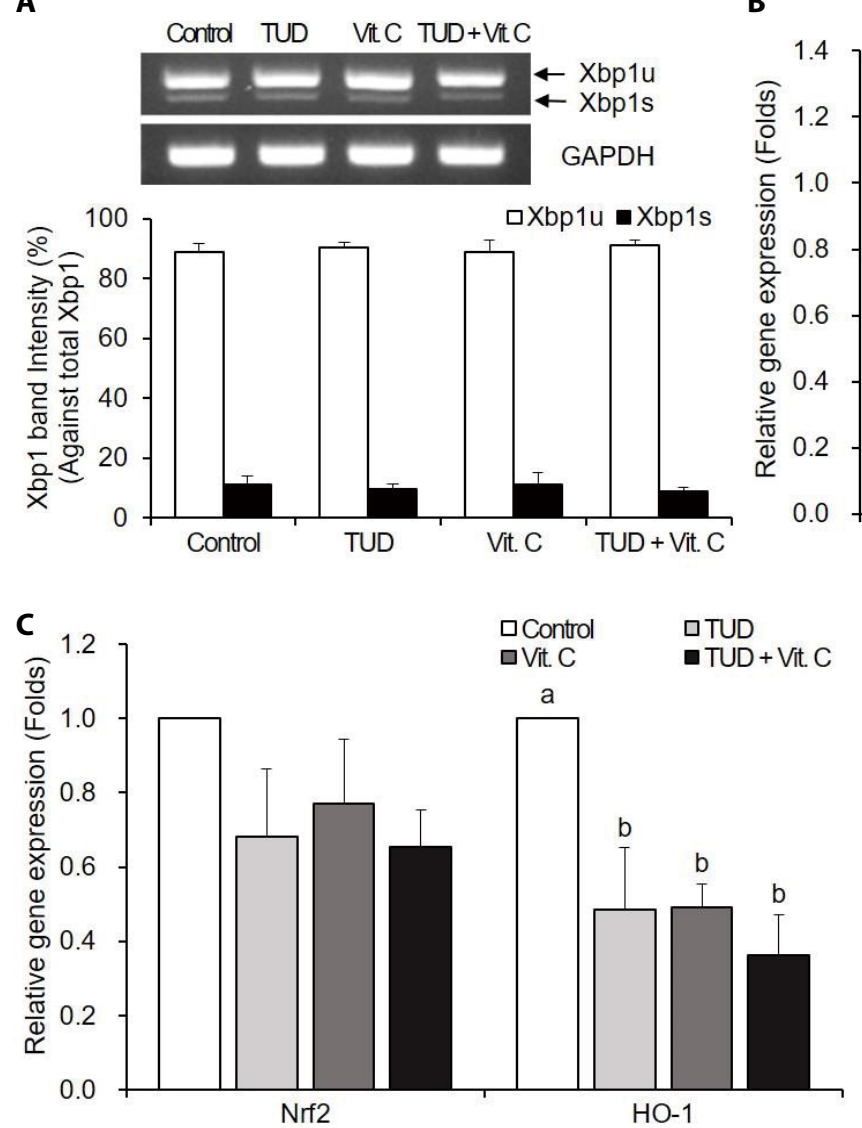

B

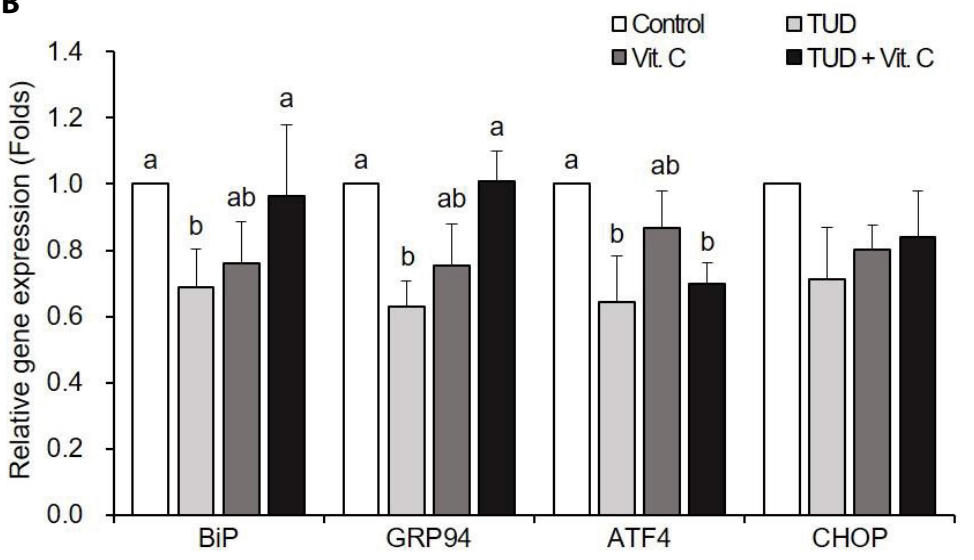

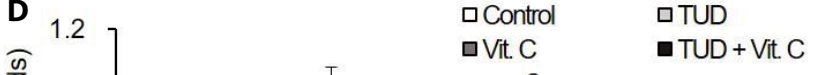

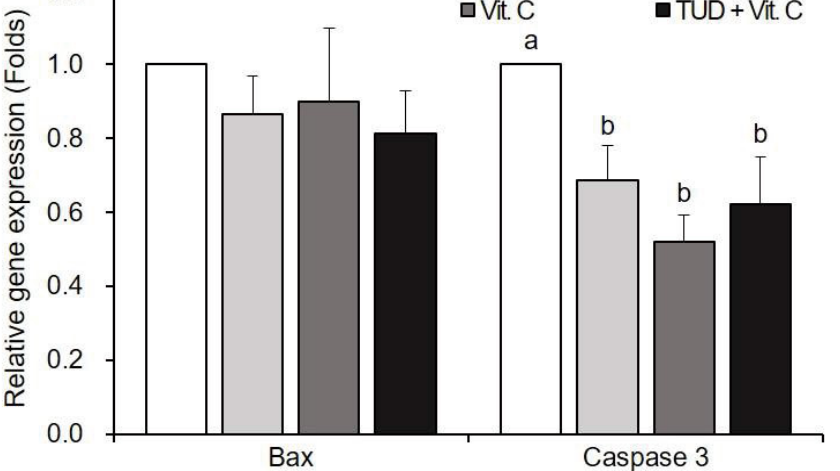

Fig. 2. Expression of Xbp1 mRNA (A), endoplasmic reticulum (ER) stress-associated genes (B), oxidative stress-associated genes (C), and apoptotic genes (D) in somatic cell nuclear transfer (SCNT) embryos at the blastocyst stage. Data are presented as means \pm SEM. TUD, 100 $\mu \mathrm{M}$ TUDCA (tauroursodeoxycholic acid); Vit. C, $100 \mu \mathrm{M}$ vitamin C; Xbp1s, spliced Xbp1; Xbp1u, unspliced Xbp1. ${ }^{\text {abb }}$ Values with different letters are significantly different $(p<0.05)$.

\section{Effects of ER stress inhibitor and antioxidant on the in vitro development of SCNT embryos}

Blastocyst formation rate was tended to increase in all treatment groups, but significantly increased in TUDCA $(24.8 \%, 55 / 222)$ and Vit. C $(22.0 \%, 53 / 241)$ treatment groups compared to the control group $(14.7 \%, 39 / 265, p<0.05)$. The mean cell number in blastocysts was significant increased in all treatment groups $(59.7 \pm 4.3$ to $63.5 \pm 3.3)$ compared to the control group $(46.2 \pm 2.6$, $p<0.05$, Table 2).

\section{DISCUSSION}

The signal pathway of UPR sensor proteins activates $A T F 4, C H O P, X b p-1$, and activating transcription factor 6 ( $A T F 6$ ), which promote the expression of ER-associated degradation (ERAD)-related genes BiP, GRP94, and ER chaperone genes to restoring the homeostasis of ER (Ron \& Walter, 2007; Senft \& Ronai, 2015). When oxidative stress occurs, Nrf2 is activated through phosphorylation. Subsequently, Nrf2 transfer to the nucleus and binds to the antioxidant elements (ARE) to regulate the expression of many antioxidant genes including superoxide dismutase 1 (SOD1), catalase and HO-1 (Cullinan \& Diehl, 2006; Nguyen et al., 2009; Zhang et al., 2015). 
Table 2. Effects of endoplasmic reticulum stress inhibitor and antioxidant treatments during micromanipulation on the in vitro development of somatic cell nuclear transfer embryos

\begin{tabular}{|c|c|c|c|c|}
\hline \multirow{2}{*}{ Treatment } & \multirow{2}{*}{$\begin{array}{c}\text { No. of } \\
\text { embryos cultured }\end{array}$} & \multicolumn{2}{|c|}{ No. of embryos developed to } & \multirow{2}{*}{ 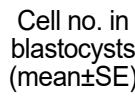 } \\
\hline & & $\geq 2-$ Cell $(\%)$ & Blastocyst (\%) & \\
\hline Control & 265 & $173(65.3)^{a}$ & $39(14.7)^{a}$ & $46.2 \pm 2.6^{a}$ \\
\hline TUD & 222 & $161(72.5)^{\mathrm{ab}}$ & $55(24.8)^{b}$ & $63.5 \pm 3.3^{b}$ \\
\hline Vit. C & 241 & $175(72.6)^{\mathrm{ab}}$ & $53(22.0)^{b}$ & $60.2 \pm 4.1^{b}$ \\
\hline TUD+Vit. C & 245 & $182(74.3)^{b}$ & $47(19.2)^{\mathrm{ab}}$ & $59.7 \pm 4.3^{b}$ \\
\hline
\end{tabular}

Experiments were repeated 6 times in each treatment group.

${ }^{a, b}$ Values with different superscripts are significantly different $(p<0.05)$.

TUD, $100 \mu \mathrm{M}$ TUDCA (tauroursodeoxycholic acid); Vit. C, $100 \mu \mathrm{M}$ vitamin C.

TUDCA is a chemical chaperone known as an ER stress inhibitor that assists protein folding and suppresses ER stress (Xie et al., 2002; Lee et al., 2010). Several studies have shown that ER stress is inhibited when TUDCA is treated to embryo or cell in culture period (Zhang et al., 2012a,b; Yoon et al., 2014; Lin et al., 2015, 2016, Mochizuki et al., 2018). In addition, our previous study showed that when TUDCA is treated during the micromanipulation and activation processes of the SCNT embryo, Xbp1s and ER stress-associated genes are significantly reduced, thereby increasing the development and quality of SCNT embryos (Park et al., 2019). This study substantiates our previous result. Interestingly, the TUDCA treatment reduced not only ER stress but also oxidative stress-associated gene transcription levels at the 1-cell stage in this study. These results suggest that TUDCA restores ER function by stabilizing protein folding and induces the decrease in ROS through uncertain mechanism.

Several studies suggested that ROS induce ER stress through regulation with UPR signaling (Cullinan \& Diehl, 2006; Eletto et al., 2014; Zhang et al., 2015). Thus, the reduction of ROS through antioxidant treatment may lead to the inhibition of ER stress. In previous study, antioxidant treatment resulted in the suppression of ER stress and increased secretion of normal protein (Malhotra et al., 2008). Also, similar results were obtained when the antioxidant $\mathrm{N}$-acetylcysteine was administered to mouse hepatocytes (Lin et al., 2013). Yoon et al. (2014) also reported that ER stress levels of SCNT embryos decreased by treatment of antioxidant during the culture period. These results corroborate our present result that antioxidant treatment during SCNT process reduced ER stress by decreasing $X b p 1$ splicing and ER stress-associated gene transcription levels in the 1-cell stage.

There was no significant decrease in the splicing of $X b p 1$ in combination with ER stress inhibitor and antioxidant. Previous study showed that the combination of ER stress inhibitor TUDCA and salubrinal did not significantly decrease the $X b p 1 s$ and ER stress-associated gene transcription levels, suggesting that simultaneous treatment of both agents would have had an excessive effect on ER (Park et al., 2019). From this point of view, a similar tendency would have been observed when the ER stress inhibitor and antioxidant were simultaneously treated. Though, the expression levels of ER stress-associated genes (BiP, GRP94, ATF4, and CHOP) and oxidative stress-associated genes (Nrf2 and HO-1) were significantly reduced at the 1-cell stage, thus combined treatment may also have an effect on reducing ER stress and ROS.

In the 1-cell stage, apoptosis was inhibited by the treatments of ER stress inhibitor and/ or antioxidant. When UPR is activated by ER stress, the activity of CHOP protein and IRE1mediated apoptosis signal-regulating kinase 1 (ASK1) / c-Jun N-terminal kinase (JNK) causes excessive $\mathrm{Ca}^{2+}$ release in the ER, resulting in increased mitochondrial $\mathrm{Ca}^{2+}$ concentration (Nishitoh et al., 2002; Zeng et al., 2015). Increased mitochondrial $\mathrm{Ca}^{2+}$ concentration activates caspase- 3 by 
the intrinsic pathway and increases apoptosis by increasing the expression of pro-apoptotic protein Bax (Song, 2012; Sano \& Reed, 2013). In particular, CHOP is involved in transcription of genes such as death receptor 5 (Dr5), which are involved in cell death, and directly affect apoptosis (Yamaguchi \&Wang, 2004). On the other hand, since antioxidant treatment can suppress apoptosis by decreasing ROS, it cannot be asserted that the decrease in apoptosis in this study is the result of the suppression of ER stress completely (Salganik, 2001; Bae et al., 2012, 2015).

ER stress inhibitor and antioxidant were not effective in preventing ER stress but affected only some of the oxidative stress-related genes and apoptotic genes in the blastocyst stage. Whereas, in previous studies, there was a difference in gene expression in the blastocyst stage when TUDCA was treated for culture period (Zhang et al., 2012a,b; Yoon et al., 2014). In this study, however, the ER stress was suppressed during only micromanipulation and activation, and the short term of initial culture rather than the whole culture period. The ER stress inhibitor treatment during the culture period would have continued to affect the expression of the genes of blastocyst. Although, when the antioxidant and / or ER stress inhibitor were treated during SCNT process in this study, there was no significant effect in ER stress and apoptosis in the blastocyst stage, the blastocyst development and cell number in blastocyst were improved.

In conclusion, ER stress and ROS are closely correlated to each other and co-regulate. Furthermore, it was illustrated that the treatment of antioxidant and / or ER stress inhibitor during micromanipulation of SCNT process can reduce the oxidative stress as well as the ER stress and the apoptosis of SCNT embryos in the early embryonic stage, and consequently promote developmental competency and the reprogramming of SCNT embryos.

\section{REFERENCES}

Bae HK, Hwang IS, Kim JY, Lee SY, Park CK, Yang BK, Cheong HT (2015) Antioxidant treatment during manipulation procedures prevents mitochondrial and DNA damage and enhances nuclear reprogramming of bovine somatic cell nuclear transfer embryos. Reprod Fertil Dev 27:1088-1096.

Bae HK, Kim JY, Hwang IS, Park CK, Yang BK, Cheong HT (2012) Inhibition of reactive oxygen species generation by antioxidant treatments during bovine somatic cell nuclear transfer. Reprod Dev Biol 36:115-120.

Bhandary B, Marahatta A, Kim HR, Chae HJ (2012) An involvement of oxidative stress in endoplasmic reticulum stress and its associated diseases. Int J Mol Sci 14:434-456.

Cullinan SB, Diehl JA (2006) Coordination of ER and oxidative stress signaling: The PERK/Nrf2 signaling pathway. Int J Biochem Cell Biol 38:317-332.

Eletto D, Chevet E, Argon Y, Appenzeller-Herzog C (2014) Redox controls UPR to control redox. J Cell Sci 127:3649-3658.

Hwang IS, Bae HK, Cheong HT (2013) Mitochondrial and DNA damage in bovine somatic cell nuclear transfer embryos.J Vet Sci 14:235-240.

Hwang IS, Bae HK, Park CK, Yang BK, Cheong HT (2012) Generation of reactive oxygen species in bovine somatic cell nuclear transfer embryos during micromanipulation procedures. Reprod Dev Biol 36:49-53.

Lee HY, Bae HK, Jung BD, Lee S, Park CK, Yang BK, Cheong HT (2018) Analysis of endoplasmic reticulum (ER) stress induced during somatic cell nuclear transfer (SCNT) process in porcine SCNT embryos. Dev Reprod 22:73-83.

Lee YY, Hong SH, Lee YJ, Chung SS, Jung HS, Park SG, Park KS (2010) Tauroursodeoxycholate (TUDCA), chemical chaperone, enhances function of islets by reducing ER stress. Biochem 
Biophys Res Commun 397:735-739.

Lin H, Liu XB, Yu JJ, Hua F, Hu ZW (2013) Antioxidant N-acetylcysteine attenuates hepatocarcinogenesis by inhibiting ROS/ER stress in TLR2 deficient mouse. PLoS One 8:e74130.

Lin T, Diao YF, Kang JW, Lee JE, Kim DK, Jin DI (2015) Tauroursodeoxycholic acid improves the implantation and live-birth rates of mouse embryos. Reprod Biol 15:101-105.

Lin T, Lee JE, Oqani RK, Kim SY, Cho ES, Jeong YD, Baek JJ,Jin DI (2016) Tauroursodeoxycholic acid improves pre-implantation development of porcine SCNT embryo by endoplasmic reticulum stress inhibition. Reprod Biol 16:269-278.

Malhotra JD, Kaufman RJ (2007) The endoplasmic reticulum and the unfolded protein response. Semin Cell Dev Biol 18:716-731.

Malhotra JD, Miao H, Zhang K, Wolfson A, Pennathur S, Pipe SW, Kaufman RJ (2008) Antioxidants reduce endoplasmic reticulum stress and improve protein secretion. Proc Natl Acad Sci USA 105:18525-18530.

Mallol A, Santaló J, Ibáñez E (2015) Improved development of somatic cell cloned mouse embryos by vitamin C and latrunculin A. PLoS One 10:e0120033.

Mochizuki M, Miyagi K, Kishigami S (2018) Optimizing treatment of tauroursodeoxycholic acid to improve embryonic development after in vitro maturation of cumulus-free oocytes in mice. PLoS One 13:e0202962.

Nguyen T, Nioi P, Pickett CB (2009) The Nrf2-antioxidant response element signaling pathway and its activation by oxidative stress. J Biol Chem 284:13291-13295.

Nishitoh H, Matsuzawa A, Tobiume K, Saegusa K, Takeda K, Inoue K, Hori S, Kakizuka A, Ichijo $\mathrm{H}$ (2002) ASK1 is essential for endoplasmic reticulum stress-induced neuronal cell death triggered by expanded polyglutamine repeats. Genes Dev 16:1345-1355.

Park HB, Park YR, Lee HY, Bae HK, Lee SH, Park CK, Yang BK, Cheong HT (2017) Endoplasmic reticulum (ER) stress and apoptosis in parthenogenetic porcine embryos following different combination of activation methods.J Anim Reprod Biotechnol 32:25-31.

Park YR, Park HB, Kim MJ, Jung BD, Lee S, Park CK, Cheong HT (2019) Effects of endoplasmic reticulum stress inhibitor treatment during the micromanipulation of somatic cell nuclear transfer in porcine oocytes. Dev Reprod 23:43-54.

Ron D, Walter P (2007) Signal integration in the endoplasmic reticulum unfolded protein response. Nat Rev Mol Cell Biol 8:519-529.

Salganik RI (2001) The benefits and hazards of antioxidants: Controlling apoptosis and other protective mechanisms in cancer patients and the human population. J Am Coll Nutr 20:464S-475S.

Sano R, Reed JC (2013) ER stress-induced cell death mechanisms. Biochim Biophys Acta 1833:3460-3470.

Senft D, Ronai ZA (2015) UPR, autophagy, and mitochondria crosstalk underlies the ER stress response. Trend Biochem Sci 40:141-148.

Song CH (2012) Endoplasmic reticulum stress responses and apoptosis. J Bacteriol Virol 42:196202.

Vannuvel K, Renard P, Raes M, Arnould T (2010) Functional and morphological impact of ER stress on mitochondria.J Cell Physiol 228:1802-1818.

Xie Q, Khaoustov VI, Chung CC, Sohn J, Krishnan B, Lewis DE, Yoffe B (2002) Effect of tauroursodeoxycholic acid on endoplasmic reticulum stress-induced caspase-12 activation. Hepatology 36:592-601. 
Yamaguchi H, Wang HG (2004) CHOP is involved in endoplasmic reticulum stress-induced apoptosis by enhancing DR5 expression in human carcinoma cells. J Biol Chem 279:4549545502.

Yoon SB, Choi SA, Sim BW, Kim JS, Mun SE, Jeong PS, Yang HJ, Lee Y, Park YH, Song BS, Kim YH,Jeong KJ, Huh JW, Lee SR, Kim SU, Chang KT (2014) Developmental competence of bovine early embryos depends on the coupled response between oxidative and endoplasmic reticulum stress. Biol Reprod 90:104.

Zeeshan HM, Lee GH, Kim HR, Chae HJ (2016) Endoplasmic reticulum stress and associated ROS. Int J Mol Sci 17:327.

Zeng T, Peng L, Chao H, Xi H, Fu B, Wang Y, Zhu Z, Wang G (2015) IRE1 $\alpha$-TRAF2-ASK1 complex-mediated endoplasmic reticulum stress and mitochondrial dysfunction contribute to CXC195-induced apoptosis in human bladder carcinoma T24 cells. Biochem Biophys Res Comm 460:530-536.

Zhang H, Davies KJA, Forman HJ (2015) Oxidative stress response and Nrf2 signaling in aging. Free Radic Biol Med 88:314-336.

Zhang JY, Diao YF, Kim HR, Jin DI (2012a) Inhibition of endoplasmic reticulum stress improves mouse embryo development. PLoS One 7:e40433.

Zhang JY, Diao YF, Oqani RK, Han RX, Jin DI (2012b) Effect of endoplasmic reticulum stress on porcine oocyte maturation and parthenogenetic embryonic development in vitro. Biol Reprod 86:128. 
